\title{
THE QUEST FOR CULTURAL SURVIVAL IN ANTONY AND CLEOPATRA
}

\author{
ANTONY VE CLEOPATRA'DA KÜLTÜREL SAĞKALIM ARAYIŞI
}

Timuçin Buğra EDMAN* - Hacer GÖZEN ${ }^{* *}$ - Lowra DZEKEM ${ }^{* * *}$

\begin{abstract}
In Antony and Cleopatra, William Shakespeare highlights the cultures of the East and the West. The play reveals the quest for cultural survival between the East and the West as a major factor that stirs cultural complexities. The unrighteous representation of the Eastern culture shows the complex nature of multiculturalism the canonical writers strove to represent in their writings. This study seeks to substantiate the challenges that confront cultural expressions in the multicultural atmosphere Shakespeare highlights in Antony and Cleopatra, as well as how the minority culture shapes this context of cultural plurality. Similarly, a comparative analysis of Cultural Studies, cultural history, cultural identity, cultural 'contents,' and the literary work Antony and Cleopatra will be the subject matter in this study. Moreover, the goal of this study is to examine how Shakespeare promotes Western culture through the adoringly and adorningly illustrated West with a blemished and contemptuous portrayal of the East in his play. Comparatively, we examine how Shakespeare evinces the triumvirs as the powerful three (Antony, Caesar and Lepidus) and, on the other hand, how he associates Cleopatra with the East.
\end{abstract}

Keywords: Gender power, cultural identity, subjected history, interculturalism, misrepresentation.

ÖZ: Antony ve Kleopatra da William Shakespeare Doğu ve Batı kültürlerini vurgular. Oyun, Doğu ve Batı arasındaki kültürel hayatta kalma arayışını, kültürel karmaşıklıkları harekete geçiren metinlerinde ortaya koyduğu çok kültürlülüğün karmaşık doğasını göstermektedir. Bu çalışma, Shakespeare'in Antony ve Kleopatra'da vurguladığı çok kültürlü atmosferde kültürel ifadelerde karşılaşılan zorlukları ve azınlık kültürünün bu kültürel çoğulculuk bağlamını nasıl şekillendirdiğini incelemeyi amaçlamaktadır. Benzer şekilde, Kültürel Çalışmalar, kültürel tarih, kültürel kimlik, kültürel 'içerikler' ile edebi eser olan Antony ve Kleopatra'nın karşılaştırmalı analizi bu çalışmanın konusu olacaktır. Dahası, bu çalışmanın amacı, Shakespeare'in oyununda Doğu'nun çirkin ve aşağılayıcı tasviriyle birlikte, hayranlık uyandırıcı ve süslü Batı tasviri aracılığılla Batı kültürünü nasıl yücelttiğini incelemektir. Shakespeare'in, hükümdarlarının (Antonius, Caesar ve Lepidus) nasıl güçlü üçlü olarak ortaya çıktıkları ve diğer yandan Kleopatra'nın Doğu ile nasıl ilişskilendirildiği karşılaştırmalı olarak incelenecektir.

Anahtar kelimeler: Cinsiyet gücü, kültürel kimlik, mahkûm edilmiş tarih, kültürlerarasılık, yanlış betimleme.

\footnotetext{
* Doç. Dr. - Düzce Üniversitesi Eğitim Fakültesi Yabancı Diller Eğitimi Bölümü İngiliz Dili Eğitimi Anabilim Dalı / Düzce - timucinbugraedman@duzce.edu.tr (Orcid ID: 0000-00025103-4791)

** Öğr. Gör. Dr. - Işıı Üniversitesi Yabancı Diller Okulu / İstanbul - hacergozen@gmail.com (Orcid ID: 0000-0001-5013-7804)

*** İstanbul Aydın Üniversitesi Lisansüstü Eğitim Enstitüsü Yüksek Lisans Öğrencisi / İstanbul - lowradzekem@stu.aydin.edu.tr (Orcid ID: 0000-0002-6768-9397) turnitin'

This article was checked by Turnitin.
} 


\section{Introduction}

William Shakespeare dramatizes the cultures of the East and the West in Antony and Cleopatra. The literary text Antony and Cleopatra divulges the quest for cultural survival of the East and the West as a crucial aspect that intermingles cultural complexities. Through the literary text, Shakespeare illustrates unjustified representations and depictions of Eastern culture and identity which demonstrates the complex nature of multiculturalism the canonical writers strove to represent in their writings. This study quest to validate the challenges that provoke cultural expression in the multicultural atmosphere Shakespeare brings to the fore in Antony and Cleopatra. This study also seeks to endorse how the minority culture forms this context of cultural plurality.

Correspondingly, this study also pursues to scrutinize how Shakespeare advocates and embraces Western culture through the language and jargon epitomizing 'the West' complimentarily and 'the East' with a contemptuous applause in his play. Comparatively, this study examines how Shakespeare evinces the triumvirs as the powerful three (Antony, Caesar and Lepidus) and, on the other hand, how he associates Cleopatra with the East.

The two important tenets, 'history' and 'culture', among many others in, enlighten this study. Cultural Studies encompasses 'history' and 'culture' in the same manner as chief canons within many others. In that sense, 'history' and 'culture' through Cultural Studies edify this study. This study focuses on Cultural Studies in interpreting Antony and Cleopatra and justifies the arguments raised.

\section{The Quest for Cultural Survival in Antony and Cleopatra}

Antony and Cleopatra should be correctly classified. It can perfectly suit tragedy, as well as Shakespeare's history plays. Although John Donne had a better understanding of the Classics and Latin than his contemporary Shakespeare, Shakespeare had a deep understanding of the Classics as well. Shakespeare learned much from Plutarch. Therefore, Plutarch is his source of inspiration and knowledge for Antony. Nevertheless, this also means that what Shakespeare knew was limited to what he had read and interpreted. Critics have different perspectives on Shakespeare's Antony and Cleopatra. Some scholars tend to especially view the end of the play as a reification of Antony, who is transformed into a mythical character. Thus, the impossible love between Antony and Cleopatra can be interpreted as an impossible love between two different people coming from totally diverse cultures. Similar to Shakespeare's The Phoenix and the Turtle, the end of the play may suggest an eternal unity of these two anomalous characters. Cleopatra as the symbol of exotic love and sex reflects both the unknown and the double edge for Shakespeare. She even loves the game of changing sexes. This might symbolize her nature, challenging whatever the Roman world is built upon. 
On the other hand, Antony is depicted as a deity for the Egyptian people, whereas he is depicted as a fallen mythical figure for the Romans, as some critics agree. The way in which Shakespeare tended to interpret the Egyptian world is very far from reality during that period. Apart from the ancient Egyptian culture, Cleopatra was not African. Rather, she was a descendant princess from Macedonia. After the collapse of the Alexandrian cities, the Ptolemaic dynasty took control of the country, which collapsed following the Roman invasion in $30 \mathrm{BC}$. Therefore, what Shakespeare dreamed about Cleopatra was false from the beginning.

Danijela Petković highlights the arguments surrounding the Renaissance era and the value of Shakespeare's works during this period. Petković refers to Greenblatt's ideas regarding the historical figures as follows: "Greenblatt's typical procedure consists of first, producing a lesserknown historical anecdote, this particular type being regarded as the literary form or genre that uniquely refers to the real" (2004: 142). Petković expresses more ideas on the views of historical critics, especially Greenblatt. Petković refers to the Renaissance period as a period through which literary figures overshadowed their works. The focus on literary figures' personalities could be equated to the trust that was given to their subject matter. In this way, it might be understandable why Shakespeare's works, one of which was Antony and Cleopatra, had high value during the Renaissance period. Althusser's statement that "there are no individuals, only subjects (with all the immediate associations of submissiveness and helplessness)" (quoted in Petković, 2004: 141; see also Althusser, 2017), simply explains why the characters represented in the plays were assigned roles that could not be changed, even by themselves. This was factually true, especially when viewed through the angle of the weaker point. Shakespeare associates the Eastern culture with Cleopatra's character as weak, helpless and submissive. Conversely, Shakespeare portrays the West as superior and powerful, associating it with the triumvirs, Antony, Caesar and Lepidus: "In Greenblatt's essays, from a 'relentless demystifier of culture' Shakespeare is masterfully turned into a 'dutiful servant, content to improvise within its [his culture's] orthodoxy'" (Petković, 2004: 141).

Shakespeare is known for his style and themes. Some readers may find that in his plays, Shakespeare valorizes the Conservative British Society as superior to any other. Moreover, in some of his plays, Shakespeare uses different foreign cultural settings. Yet, Shakespeare does not let the audience/reader explore the cultural values of the foreign places to which he refers. For instance, despite equally and objectively representing the cultural values of his nation and Egypt, or utilizing cultural traits from both cultures equally adoringly and adorningly, illustrating both of them, Shakespeare posits that the West is superior to the East, personifying the history and culture through such characters as Antony, Caesar, Lepidus and Cleopatra. In Antony and Cleopatra, readers know it takes place in Egypt, especially in the opening scene, because Shakespeare reveals it to the 
audience. However, Shakespeare does not touch upon deep-rooted Egyptian history or culture in the way he sets the scene to enable the audience to comprehend the foreign nation presented. Rather, Shakespeare treats the deep-rooted history and culture of Egypt with triviality.

In a similar manner, Petković refers to Greenblatt's argument that Shakespeare uses "oppressive force which subjugates us, without allowing sufficient space for the realities of ideological struggle..." (2004: 141). Shakespeare gives English culture an oppressive force over Eastern culture. This is observed in the way Cleopatra is not presented by her strengths, with her real qualities of an Egyptian queen. She is not an ordinary citizen, and Shakespeare chooses her as a symbol representing Egyptian culture. Yet, despite her state of being a majestic rule and a figure of power in majestic Egypt, Cleopatra is portrayed as worthless, weak, and merely a symbol of sexuality. It is important to note that the intended portrayal of weakness in Cleopatra's persona might speak to a hidden power which also ridicules the valorized cultural symbol of the West: Antony. The underlying themes of love and sex in the play make it almost impossible for both sides to be triumphal. However, contrary to the fictional facts presented in the play, Cleopatra fights back culturally. Her cultural influence causes Antony's death. This is almost symbolic with cultural victory, which is not a focus of Shakespeare. That is to say, the East wins in the end.

The highlighted historical influence of the Renaissance period in Shakespeare's works, especially in Antony and Cleopatra, provides additional submeanings to the text, which are possible to interpret or comprehend through the Cultural Studies angle:

Cultural identity defines a junction between how a culture defines subjects and how they imagine themselves. ... cultural identity is framed in terms of a collective 'one true self' which people with a shared history and ancestry have in common and which is preserved through changes of fortune and vicissitudes of history. Cultural identity, in its sense, is a stable, consistent feature that unifies people, particularly during periods of struggle. (Hall cited in Cashmore, 2004: 95; see also Hall cited in Storry and Peter, 2002)

The preeminent foresight Cashmore envisions is that culture comprises identity. He divulges how cultural identity binds a group of people together, especially under traumatic experiences or through crises. Within the context of Antony and Cleopatra, the reader can see how Shakespeare distinguishes the cultural identities of Rome and Egypt through Antony and Cleopatra's personas, as well as many other characters in the play. Shakespeare's text reveals how cultural identities strive for self-identity in history, and how foreign cultural identities are obscured by the mainstream cultures in the West. For Hall, identity is a "'production,' which is never complete, always in process, and always constituted within, not outside, representation" (cited in Storry and Peter, 2002: 210). Hall further elucidates, "Identities are the names we give to the different ways we are positioned by, and position ourselves within, the narratives of the past" 
(cited in Storry and Peter, 2002: 213). In this regard, it might be asserted that an identity cannot be characterized with a fixed definition, as identity conduces change through geography, culture, and experience. In order to contextualize Hall's argument within Shakespeare's text in Antony and Cleopatra, the projection of geographical boundaries through the shift of scenes would promote this for the reader. The shifting scenes of geographical boundaries reveal the cultural identities in the play, which are not merely nomenclatures created by Shakespeare. In addition to the shifting scenes of geography in the play, the generous use of English names by Shakespeare illustrates the West's cultural dominance over the East. On the contrary, the sexuality personified in Cleopatra that captures Antony demonstrates not only the strive for cultural survival of the East, but also the victory of Eastern culture when Antony dies due to, and for the sake of his love for, Cleopatra. The preeminence of English names in the play discloses Shakespeare's inclination toward cultural authenticity and cultural authority, which is conspicuously the West.

Before steeping in Shakespeare's language in Antony and Cleopatra, an insight into the philosophy of cultural authenticity and cultural authority would enlighten this study. In his book Culture and Authenticity, Chares Lindholm outlines "authenticity" as "a series of comparative case studies" while he analyzes many cultures and nations through historical, political and cultural angles (2008: 2). Lindholm reveals the association between 'authenticity' and nations. Furthermore, Lindholm advocates that 'authenticity' designates pureness, originality and reality in aspects, spirituality, personas or cultures: "Authentic objects, persons and collectives are original, real, and pure; they are what they purport to be, their roots are known and verified, their essence and appearance are one" (2008: 2). For Lindholm, people pursue their origin and essence, that is to say, they quest for their 'authenticity' and 'the pure and original' identity which is 'real self'. On the other hand, Lindholm also states that 'authenticity' is so easily corrupted, manipulated or shifted that throughout political, social or historical process 'authenticity' loses its roots, originality and its essence in reality, and ambiguity occurs in the perception of what real is $(2008: 2,3,50$, 67).

In his book The Jargon of Authenticity, Theodor W. Adorno exposes how the Jargon and authenticity function in the meaning, truth or objectivity in the language:

Use of existentialistic terms became, Adorno argues, a jargon: a mode of magical expression... Adorno's critique focuses on the jargon's incapacity to express the relation between language and truth, in that it breaks the dialectic of language by making the intended object appear present by the idealization inherent in the word itself. The jargon, therefore, falls into an objectivism that conceals the difference between philosophical reflection and the in-itselfness of the object of reflection. Such objectivism loses the intent of reflection to maintain a self-consciousness of the mediation of fact through the thinking 
subject. Consequently, in the jargon objective consciousness is compressed into self-experience, and an idealism results. The jargon has at its disposal a modest number of words which are received as promptly as signals. 'Authenticity' itself is not the most prominent of them. It is more an illumination of the ether in which the jargon flourishes, and the way of thinking which latently feeds it. ...The search for meaning as that which something is authentically, and as that which is hidden in it, pushes away, often unnoticed and therefore all the faster, the question as to the right of this something. Analysis of meaning becomes the norm in this demand, not only for the signs but also for that to which they refer (1973: 8-9, 38-40).

For Adorno, the analysis and critique of language may help reveal the real in meaning and authenticity in the language.

Moreover, Reino Virtanen is one of the prominent scholars who evinces cultural solipsism in Western culture, literature and philosophy in his essay "The Spectre of Solipsism in Western Literature". Virtanen reveals that solipsism is an eminent context in western literature and philosophy:

It is reported that a self-styled solipsist once expressed surprise that there were no others. The reasoning that had led to the view that nothing was real outside the personal self seemed to be so overwhelming that it was hard to understand how anyone could avoid being convinced. That self-styled solipsist could not have done much reading in modern Western literature. ...In our survey of the subject, clarity requires that we find a place for a third type of reference, a more superficial one. Webster's Dictionary defines this type as 'extreme indulgence of and concern with the self at the expense of social relationships.' It has been attributed to Romantics as diverse as Werther, Rene, Faust, and Ahab. The misleading application of the word is not without cultural significance in itself. The predilection for its use is perhaps a symptom of a malaise affecting society. Thus it may be more than a faddish catchword for the many literary critics and scholars who are using it nowadays (Virtanen, 1986: 74).

For Virtanen, the cultural solipsism is so common in Western literature and philosophy that he nominates them as Robinson Crusoes: "The frequency of occurrences suggests that the problem is latent in modern sensibility, and especially in the vaunted individualism of the West, represented by a crowd of Robinson Crusoes of introspection, so unique to themselves yet after all so much alike" (1986: 60).

Cultural identity is "in terms of one, shared culture, a sort of collective 'one true self,' hiding inside the many other, more superficial or artificially imposed 'selves,' which people with a shared history and ancestry hold in common" (Hall, 1990: 223). Hall simply elucidates how cultural identities are engendered. It is particularly cultural traits that bind people together. The descent of 'one true self,' which is cultural identity, emerges through social crises, socially traumatic experiences or social deprivations, just as that which emerged after colonialist policies were imposed on Africans (see Frantz Fanon cited in Hall, 1990; see also Frantz Fanon, 1994; Homi K. Bhabha, 1990). In this sense, if regarded in a reverse manner, the superficial 
or artificially imposed many 'selves' in a society encompass a hidden 'one true self' which emerges only in cases of social crisis or social deprivation. In other words, in the play, Shakespeare deprives Cleopatra's identity despite her ancestral heritage of sovereignty, which is a notion of cultural and social crisis for her and her identity, and which engenders her cultural identity a 'collective one true self,' or a shared cultural Egyptian identity. On the other hand, viewed in reverse, the superficial or artificially imposed 'selves' might be delineated as Western culture in the play. Through cultural encounters, Shakespeare's manner of naming characters and merging cultures with a portrayal of the supremacy of Western culture over the East suggest, rather, a forced shared culture, and more superficial and more artificially imposed 'selves' with regard to cultural identities, which do not serve to hold the nation.

Graeme Turner defines language in his book, British Cultural Studies, as follows: "Language is a signifying system that can be seen to be closely ordered, structured, and thus can be rigorously examined and ultimately understood; conversely, it is also a means of 'expression' that is not entirely mechanistic in its functions but allows for a range of variant possibilities" (2014: 337). Language encompasses a system that renders it unique. Each language has a particular structure unique from other languages. Each structured form of language engenders an exclusive expression.

In Antony and Cleopatra, Shakespeare uses the English language and even English names through a unique expression to write his text, which acclaims Western culture in its subtext. Notwithstanding, Shakespeare does not admire the Eastern languages as a momentous cultural work of integrity worth nominating as a subject matter in his play. According to David Christopher, "English is a hybrid, a linguistic 'stew' which has absorbed varied elements of speech brought by ancient conquering tribes and nationalities" (1999: 23).

Additionally, Homi K. Bhabha defines cultural diversity as follows: '[c]ultural diversity is the recognition of pre-given cultural 'contents' and customs, held in a time-frame of relativism; it gives rise to anodyne liberal notions of multiculturalism, cultural exchange, or the culture of humanity" (1995: 206; see also Grenfell 2014; Simal, 2002). Bhabha appreciates and acknowledges the development of multiculturalism and the culture of humanity. In that regard, cultural exchange or cultural diversity is not an obstacle for the nations in respecting others' ancestral inheritance. Despite the fact that the English language embraces multiple cultures, and notwithstanding that Shakespeare envisions two distinct cultures in his play, he propounds to delineate one superior over the other rather than enrich the cultural integrity or multiculturalism of the play. Rather than embellishing the cultural dignity of both nations, Shakespeare promotes and advocates Western culture, which is personified as supreme in the character Antony. 
In the opening scene of Act I, Antony is in Egypt. Philo and Demetrius gossip about Antony, who has fallen in love with the Egyptian Queen Cleopatra. Yet, Philo and Demetrius do not see Cleopatra as equal in power to Antony. They regard her more for her sexuality rather than her dignity or power in her nation. They despise Eastern culture, depicting it as inferior in the embodiment of Cleopatra, who is regarded as unequal to Antony. Despite the veiled multiculturalism in the play, the only thing that gives readers a clue about the East is when readers are informed that the scene takes place in Egypt just as the play starts, when Antony is in Egypt. With the exception of the geographical or locational indication of Egypt in the play, the play does not introduce any other cultural 'contents' or customs, neither throughout the text nor the subtext. The culture of humanity, multiculturalism and cultural exchange are not the themes of the play. Rather, Western cultural dominance and the quest for cultural survival by the East is evident in the play.

Haegap Jeoung refers to Sigmund Freud's psychoanalysis theory in approaching William Shakespeare's Antony and Cleopatra within the context of Orientalism. Jeoung argues that Shakespeare's Antony and Cleopatra is an attempt to show the binary relationship between the West and East and valorizes the east as 'other.' Additionally, Jeoung constantly refers to Eastern people as 'uncanny other' (2003). For Jeoung, in Western culture, the East is perceived as the 'other.' Jeoung expatiates on the fact that power relations in Shakespeare's plays reveal a 'psychological other,' especially in Antony and Cleopatra, which posits the Western culture to be at a pivotal point within supremacy.

Cleopatra was the sole empress of Egypt; on the other hand, Antony was sharing the rule with two others. Yet, in the play, she is depicted as a temptress and a gipsy who is unequal to King Antony. While Antony is "the triple pillar of the world" (Shakespeare, 2005: 5), and Caesar is "most noble" (Shakespeare, 2005: 26), Cleopatra is "a strumpet" (Shakespeare, 2005: 6):

That o'er the files and musters of the war

Have glow'd like plated Mars, now bend, now turn,

The office and devotion of their view

Upon a tawny front: his captain's heart,

Which in the scuffles of great fights hath burst

The buckles on his breast, reneges all temper,

And is become the bellows and the fan

To cool a gipsy's lust. (Shakespeare, 2005: 5)

Even through the utterances of Cleopatra, any emperors of Rome were superior to Cleopatra, as she herself depicts and degrades her self-being into the woman of a man, either young or old, without any other quality except being merely a female: 
[Cleopatra]: The demi-Atlas of this earth [Cleopatra talking about Antony], the arm

And burgonet of men.--He's speaking now,

Or murmuring 'Where's my serpent of old Nile?'

For so he calls me.--Now I feed myself

With most delicious poison:--think on me,

That am with Phoebus' amorous pinches black,

And wrinkled deep in time? Broad-fronted Caesar,

When thou wast here above the ground I was

A morsel for a monarch: and great Pompey

Would stand and make his eyes grow in my brow;

There would he anchor his aspect and die

With looking on his life (Shakespeare, 2005: 30).

In the play, despite the fact that Shakespeare does not provide any direct references to the historical data about Rome or Egypt, the subtext of the play refers to significant portrayals of both empires. For example, Egypt is associated with the Nile, which is referred to as quite old and infested with flies, snakes and crocodiles. Through the text of the play, the river Nile is associated with wild crocodiles, harmful flies, and poisonous snakes, worms or venomous creatures, and Egypt and Cleopatra are associated with the Nile or snakes. Cleopatra is the "serpent of old Nile," and Antony is "The demiAtlas of this earth" (Shakespeare, 2005: 30, for the association of Egypt and Cleopatra to the Nile and snakes see also 18, 57, 69, 70, 155, 177, 178, 179). It is significant that Shakespeare prefers to end Cleopatra's life via the most dangerous and poisonous snake of the Nile, while Antony dies via a sword.

There is no reference to the power of the Empire in Egypt, despite the fact that it is one of the oldest powerful empires in history. However, the text provides many references to the power of the Roman Empire. Shakespeare exposes some traces in citing the power of Rome. The kings of Rome are the most powerful by land and by sea:

ANTONY.

What is his strength

By land?

CAESAR.

Great and increasing; but by sea

He is an absolute master (Shakespeare, 2005: 45).

Shakespeare does not content himself with associating the king's omnipotence with 'lands' or 'sea', and he goes further underscoring an immense state of power which is associated with a limitless line from the east to the west, form the north to the south:

MESSENGER.

Labienus,-- 
This is stiff news,--hath, with his Parthian force,

Extended Asia from Euphrates;

His conquering banner shook from Syria

To Lydia and to Ionia;

Whilst,-- (Shakespeare, 2005: 14).

Accentuating an everlasting and borderless lines might have fallen short for Shakespeare that he illustrates the kings of Rome as if they are the avatars of [the] god in the world:

POMPEY.

To you all three [refers to the kings of Rome],

The senators alone of this great world,

Chief factors for the gods (Shakespeare, 2005: 60).

Shakespeare manifests that the kings of Rome are the sole possessors of the world despite many other kingdoms or nations were also reigning during that time. Shakespeare seems neglecting all of the other kingdoms:

MENAS [refers to the kings of Rome].

These three world-sharers, these competitors (Shakespeare, 2005: 72).

However, associating the kings of Rome as the sole omnipotent and gods of the world is not sufficient that Shakespeare adds another degree for the kings of Rome carrying their power beyond the world to the universe:

ENOBARBUS.

Caesar? Why he's the Jupiter of men.

AGRIPPA.

What's Antony? The god of Jupiter (Shakespeare, 2005: 79).

Yet, in contrast to the kings of Rome, Egypt is referred to as the center of joy and feasting in the play despite the deep-rooted history and reign in Egypt:

\section{MAECENAS.}

We have cause to be glad that matters are so well digested. You stay'd well by it in Egypt.

ENOBARBUS.

Ay, sir; we did sleep day out of countenance, and made the night light with drinking (Shakespeare, 2005: 45-46).

One of the well-known lines form Antony and Cleopatra also signifies how the king of Rome loses his manly skills as a warrior and king in Egypt reflecting Antony's regret being in Egypt.

ANTONY [refers to Egypt].

The beds i' the East are soft; and, thanks to you,

That call'd me, timelier than my purpose, hither;

For I have gained by it (Shakespeare, 2005: 62). 
'The beds i' the East' might be interpreted as Antony's sexual affairs with Cleopatra. The line also associates Cleopatra as a sexual figure who weakens a man and deprives him from his manly skills and power. Besides, it is conceivable that Shakespeare associates Egypt with feminine sexuality referring to the 'bed' and with feminine weakness rather than being a reign in the East defining the East as 'soft':

POMPEY.

No, Antony, take the lot: but, first

Or last, your fine Egyptian cookery

Shall have the fame. I have heard that Julius Caesar

Grew fat with feasting there (Shakespeare, 2005: 63).

Egypt is identified as a dazzling seductress with sexuality and joy. In the play, the lines leave no space for Egypt as a kingdom or Cleopatra as the reign of Egypt:

ENOBARBUS.

[To ANTONY.]

Ha, my brave emperor!

Shall we dance now the Egyptian Bacchanals [traditional Egyptian dance]

And celebrate our drink? (Shakespeare, 2005: 74).

The subtext portrays the emperors of Rome and signifies their power:

Caesar and Lepidus

Are in the field: a mighty strength they carry (Shakespeare, 2005: 34).

The kings of Rome have an army of strength, dignity and courage, and they are surrounded by courageous soldiers throughout the play. On the contrary, Cleopatra is surrounded by maidens who are beautiful. Although Cleopatra is associated with sexuality as a femme fatale, Antony is affiliated with warriors:

POMPEY.

He dreams: I know they are in Rome together,

Looking for Antony. But all the charms of love,

Salt Cleopatra, soften thy wan'd lip!

Let witchcraft join with beauty, lust with both!

Tie up the libertine in a field of feasts,

Keep his brain fuming; Epicurean cooks

Sharpen with cloyless sauce his appetite;

That sleep and feeding may prorogue his honour

Even till a Lethe'd dullness (Shakespeare, 2005: 34; see also 46-49).

In contrast to Cleopatra, the female characters in Rome, Octavia, sister to Caesar and wife to Antony, and Fulvia, ex-wife to Antony, are personified as dignified, warriors, gracious, and talented political figures in the play:

ANTONY: As for my wife, 
I would you had her spirit in such another [refers to Fulvia]:

The third o' theworld is yours; which with a snaffle

You may pace easy, but not such a wife.

ENOBARBUS.

Would we had all such wives [refers to Fulvia], that the men

Might go to wars with the women.

On the contrary to Octavia or Fulvia, in the play, the only female figure who is the reign of a nation was Cleopatra. Yet, Octavia and Fulvia are personified as dignified political figures:

ANTONY.

So much uncurbable, her [refers to Fulvia] garboils, Caesar,

Made out of her impatience,--which not wanted

Shrewdness of policy too,--I grieving grant

Did you too much disquiet: for that you must

But say I could not help it

-..

\section{AGRIPPA.}

Thou hast a sister by the mother's side,

Admir'd Octavia. (Shakespeare, 2005: 39, 40 43; see also 44, 46, 49, 51; for the depiction of Octavia as the association of Roman Empire see also 92-93; for depiction of Cleopatra as a sexual tempter see also 94)

Neither Octavia nor Fulvia were rulers of Roman Empire, as they were merely a wife to a king and the sister of a king. However, they were personified as powerful political figures. On the contrary, despite being the sole ruler of Egypt and the figure of a goddess in Egyptian myth, Cleopatra is signified as simply a woman:

CANIDIUS.

Soldier, thou art: but his whole action grows

Not in the power on't: so our leader's led,

And we are women's men [refers to Cleopatra]. (Shakespeare, 2005: 99; see also 100-107, 143-144)

In Antony and Cleopatra, the portrayal and depiction of the intermingled story and adventures of the East and the West spawn cultural identities that are introduced to the audience. As Shakespeare reveals two different cultures and identities in the play, he binds the people of the East and the West in the play as well. However, the cultural identities of the East and the West Shakespeare surfaces are highly superficial and artificially constructed that represents delusive cultural identities. The artificially imposed 'selves' of the East and the West are underscored so strikingly that it is highly impossible to trace the cultural survival of the East. Furthermore, in Antony and Cleopatra, Shakespeare emerges a new cultural identity for the West and introduces or imposes a new cultural identity to the East. The 
cultural identity of the East Shakespeare composes through the literary language and words in the text is inferior to the West. The audience is imposed to apprehend the East as the inferior to the West through the sublines and sub meaning of the language Shakespeare masterfully composes. Shakespeare divests the 'one true self' of the East, which has deep-rooted ancestral heritage of sovereignty, and reconstruct a new artificial cultural identity for the East that is weak, impotent and inferior to the West, which is portrayed as the cultural supremacy over the East.

Even though Shakespeare incorporates multiple cultures which might have been envisioning the cultural integrity or multiculturalism in the play, the language, the wording and the illustrations Shakespeare appreciates engenders two distinct artificial cultures through the personas of the kings of Rome and the queen Cleopatra: the superior Western culture and identity over the inferior Eastern. Likewise, in Antony and Cleopatra, it might be commentated that Shakespeare posits a cultural solipsism, a self-styled solipsist vision as if 'there were no others'. As afore mentioned in Adorno's appraisal (1973: 8-9, 38-40), the jargon in Antony and Cleopatra is incompetent to assert the coherence between language and truth. The language Shakespeare insinuatingly conveys the 'object', which is the Western culture in the play, as the epitomized idealization in the words. Namely, the jargon Shakespeare uses is subjective and digresses from authenticity.

Moreover, Lyam Ortmeier (2008) analyzes the early modern orientalism in Shakespeare's Antony and Cleopatra, and divulges that in the play, Egypt is like any other African country, a foreign land of prospective colonizers. Ortmeier remarks that the 'River Nile' symbolizes the aftermath binaries of colonizers and the colonized. Ortmeier notes that space and place are geographical symbols which the critic uses to demonstrate the disrespect toward boundaries in terms of cultures. Power and its relationships submerge the allegedly 'weak' but contextualize the Eastern culture within the backdrop of Edward Said's Orientalism, neutralizing the claimed power by the West. Shehla Burney articulates that Said "raises the issue of the feminization of the Orient by citing relationships between Flaubert and an Egyptian courtesan. This encounter, Said suggests, 'produced a widely influential model of the Oriental woman'" (2012: 33), and the literary allusion here can be tied to that of Antony and Cleopatra.

\section{Conclusion}

In Antony and Cleopatra, William Shakespeare intermingles Eastern and Western cultures, which represents a quest for cultural survival between the East and West through cultural complexities. In this study, through the comparative analysis of cultural history, cultural identity, cultural 'contents,' and the literary work Antony and Cleopatra, it is revealed that the unrighteous illustration of Eastern culture and history dominates in this play by Shakespeare. On the other hand, throughout the play, 
Shakespeare advocates for Western culture through his admiring portrayal of the West.

Shakespeare splendidly and competently uses English language as the valorization of the Western culture over the Eastern. In the play, despite being the reign of Egypt, Cleopatra is degraded as a 'woman' while the Roman queen and princess are personified as the political figures. Cleopatra is associated with feminine sexuality as a femme fatale. Even, through Cleopatra's own utterances, Shakespeare degrades Cleopatra. Shakespeare posits Cleopatra in such a manner that she degrades her self-being into the woman of a man and sexuality, depriving her self-being from being the sovereignty of Egypt, a powerful political figure or an empress. The language and the jargon of the text delineate Cleopatra as a temptress and a gipsy who is unequal to King Antony. Cleopatra is signified as the serpent of the Nile, which is rather old and infested with flies, snakes and crocodiles. The Nile is almost synonymous with Egypt, the Eastern culture and identity, inferior to the West. In the play, the Western identity personified through the kings of Rome is the sole omnipotent being signified as the gods of the world and Jupiter. On the contrary, the text leaves no space for the authenticity of the Eastern culture, of the Empire in Egypt. For the East, a superficial cultural identity is constructed through the literary text and language in the play. The inferior state of the East across the supremacy of the West is flourished in the end of the play as well via the deaths of Cleopatra and Antony; Cleopatra dies by inches with the poison of the most perilous snake of the Nile, while Antony dies by the sword as he lived by the sword.

In Antony and Cleopatra, William Shakespeare has been shown to valorize Western culture over the East. On the other hand, the quest for cultural survival has been seen through the misrepresentation of Eastern culture through Cleopatra. Her sexuality is presented as trivial, but it is a very important key to her cultural power. Antony, who is presented by Shakespeare as a strong cultural symbol, is ruined by it. This shows not only his failure as a ruling power, but also as a symbol of a collapsing British culture. It also demonstrates Shakespeare's weakness as a collapsing Renaissance hero whom Stephen Greenblatt deconstructs in his argument. 


\section{REFERENCES}

Adorno, T. W. (1973). The Jargon of authenticity. (Trans. Knut Tarnowski and Frederic Will, Evanston), IL: Northwestern University Press.

Althusser, L. (2017). Ideology and ideological state apparatuses. Literary Theory: An Anthology. (Eds.: Julie Rivkin, and Michael Ryan), UK: Wiley Blackwell publishing (John Wiley \& Sons), 768-777.

Bhabha, Homi K. (1994). Cultural diversity and cultural differences. Post-Colonial Studies Reader. (Eds.: Bill Ashcroft, Gareth Griffiths and Helen Tiffin), Taylor \& Francis Group.

Burney, S. (2012). CHAPTER ONE: Orientalism: The making of the other. Counterpoints, 417, 23-39.

Cashmore, E. (2004). Encyclopedia of race and ethnic studies. London and New York: Routledge.

Christopher, D. (1999). British culture: An introduction. London and New York: Routledge.

Fanon, F. (2004). The wretched of the earth. (Translated from the French by Richard Philcox with commentary by Jean-Paul Sartre and Homi K Bhabha), New York: Grove Press.

Grenfell, D. (2014). Diversity and the discourses of security and interventions. The SAGE Handbook of Globalization, (Ed.: Manfred Steger; Paul Battersby; Joseph Siracusa), London: Sage.

Hall, S. (1990). Cultural identity and diaspora. Identity: Community, Culture, Difference, (Ed.: J. Rutherford), London: Lawrence \& Wishart.

Homi K. B. (ed.). (1990). Nation and narration. London and New York: Routledge.

Jeoung, H. (2003). An Africanist-orientalist discourse: the other in Shakespeare and Hellenistic tragedy. Louisiana State University Doctoral Dissertations. Comparative Literature (Interdepartmental Program) https://digitalcommons.lsu.edu/gradschool_dissertations/1532

Lindholm, C. (2008). Culture and authenticity. Oxford, UK: Blackwell Publishing.

Ortmeier, L. (2008). Translating orientalism: Modes of producing the oriental other in Shakespeare's Antony and Cleopatra. Berlin: Freie Universität Berlin.

Petković, D. (2004). Shakespeare, culture, new historicism. Linguistics and Literature, 3 (1), 139-149.

Shakespeare, W. (2005). Antony and Cleopatra. USA: Icon Classics

Simal, B. (2002). "The Cariboo Café" as a border text: The holographic model Benito. Literature and Ethnicity in the Cultural Borderlands, (Eds.: Jesus Benito, Ana María Manzanas), NY: Rodopi.

Storry, M - Child P. (Eds.). (2002). British cultural studies. London and New York: Routledge.

Turner, G. (2014). British cultural studies: An introduction. London and New York: Figueroa Press. 
Virtanen, R. (1986). The spectre of solipsism in western literature. The Journal of the Midwest Modern Language Association, Spring, Vol. 19, No. 1, 59-76.

İyi Yayın Üzerine Kılavuzlar ve Yayın Etiği Komitesi'nin (COPE) Davranış Kuralları" çerçevesinde aşağıdaki beyanlara yer verilmiștir. / The following statements are included within the framework of "Guidelines on Good Publication and the Code of Conduct of the Publication Ethics Committee (COPE)":

İzinler ve Etik Kurul Belgesi/Permissions and Ethics Committee Certificate: Makale konusu ve kapsamı etik kurul onay belgesi gerektirmemektedir. / The subject and scope of the article do not require an ethics committee approval.

Çıkar Çatışması Beyanı/Declaration of Conflicting Interests: Bu makalenin araștırması, yazarlığı veya yayınlanmasıyla ilgili olarak yazarların potansiyel bir çıkar çatışması yoktur. / There is no potential conflict of interest for the authors regarding the research, authorship or publication of this article.

Katkı Oranı Beyanı/Author Contributions: Makale, yazarların ortak çalıșması ile hazırlanmıștır. Makalenin araştırma, inceleme, analiz, yazım ve düzenleme aşamaları için iş birliği sağlanmıștır. /The article has been prepared with the collaboration of the authors. Cooperation was provided for the research, analysis, analysis, writing and editing stages of the article. 